\title{
Population biology of the burrowing crab Neohelice granulata, (Crustacea: Decapoda: Varunidae) from a tropical mangrove in Brazil
}

\author{
Rafael A. Gregati \& Maria L. Negreiros-Fransozo
}

\begin{abstract}
Núcleo de Estudos em Biologia, Ecologia e Cultivo de Crustáceos, Instituto de Biociências, Departamento de Zoologia, Universidade Estadual Paulista.18618-000, Botucatu, São Paulo, Brasil.E-mail: gregati@ibb.unesp.br; mlnf@ibb.unesp.br
\end{abstract}

\begin{abstract}
The population biology of the burrowing crab Neohelice granulata (Dana, 1851) from a mangrove in Jabaquara Beach, Paraty, state of Rio de Janeiro, Brazil $\left(23^{\circ} 13^{\prime} 04^{\prime \prime} \mathrm{S}\right.$ and $\left.44^{\circ} 42^{\prime} 47^{\prime \prime} \mathrm{W}\right)$, was studied with respect to the following traits: size-frequency distribution, recruitment, reproductive period, fecundity, and sex ratio. Specimens were sampled monthly from April, 2003 to March, 2004, at the river margins during low tide periods. Size, sex, presence of eggs, and stage of the female gonad were recorded. Ovigerous females had their eggs removed and counted. The reproductive period was continuous and the highest frequency of ovigerous females was recorded in the fall and winter. Mature gonads were found throughout the year and recruitment was continuous but more intense during the summer. The fecundity of $N$. granulata (30028.3 \pm 10861.2 eggs) was high in comparison to studies in other localities. In general, the proportion of males was similar to that of females (1:0.92); however, males were predominant in the fall (1:0.77) and winter (1:0.75). All the information available so far on the reproduction of $N$. granulata involves populations from subtropical salt marshes; therefore, comparative studies including other habitats, such as mangrove forests, are needed to further understand the environmental influences on the population and reproductive biology of semiterrestrial crabs.

KEY WORDS. Grapsoidea; population structure; semiterrestrial crab.
\end{abstract}

A structural characterization of populations is essential for the preservation of natural resources. Such data can be employed in ecological studies concerning spawning, mortality, growth and migration, for example (HuTCHINSON 1981).

The studies on the reproductive biology and the considerable diversity of life cycles observed in Brachyura include sexual maturity (GonZÁlez-GurRiarán \& Freire 1994), reproductive period (Atrill et al. 1991) and fecundity (Luppi et al. 1997). Determining the reproductive cycle is fundamental to understand the population biology (HenMi 1989), providing valuable information for the establishment of programs or management plans for commercially important species or animals living in protection areas, such as mangroves in the Brazilian territory (Kennelly \& Watkins 1994).

According to the theory of Fisher (1930), the proportion of males to females at birth tends to be 1:1 in natural populations. After birth, several factors can affect such relationship, regardless of sex. Variations in sex proportion have been reported in crab populations, which can be explained by longevity and mortality rates, sexual reversion or sexual predation (WENNER 1972).

The semiterrestrial crab Neohelice granulata (Dana, 1851) (= Chasmagnathus granulatus) is an important burrowing species in intertidal areas from tropical and subtropical estuaries in South America. It occurs in the West Atlantic Ocean in Brazil (from Rio de Janeiro to Rio Grande do Sul), Uruguay, and
Argentina (Melo 1996). This crab species moves great amounts of sediment for feeding purposes and gallery maintenance, influencing substrate quality, penetrability and transportation (BotTo \& IrIBARNe 2000).

To date, all reports available on $N$. granulata reproduction involve populations from subtropical salt marshes (STELLA et al. 1996, López et al. 1997, López-Greco \& RodríGuez 1999, Luppi et al. 2004). Thus, the aim of this paper was to provide new data on the population and reproductive biology of $N$. granulata from a tropical mangrove ecosystem in the Brazilian coast.

\section{MATERIAL AND METHODS}

Samples were obtained monthly during low tide periods, from April, 2003 to March, 2004, in the mangrove of the Jabaquara Beach, Paraty, Rio de Janeiro State, Brazil (2313'04"S, $\left.44^{\circ} 42^{\prime} 47^{\prime \prime} \mathrm{W}\right)$. Crab specimens were either manually removed from their burrows or collected as they were walking freely on the muddy bottom. We utilized the catch per unit effort, with two collectors simultaneously sampling in the same site for 15 minutes each, scanning an area of approximately $5 \mathrm{~m}^{2}$ in each of the three sampling sites along the river margin.

Crabs were kept in plastic bags (ovigerous females kept separated from other specimens) and refrigerated until analysis. In the laboratory, the sex of each crab was assessed by observing the abdomen morphology (presence of gonopods in males or four pairs of plumose pleopods in females). The cara- 
pace width (CW) of each specimen was measured with a digital caliper $(0.01 \mathrm{~mm})$. Ovigerous females had their total egg mass carefully removed and kept in 70\% ethanol.

Following the measurements, each female specimen was dissected for macroscopic observation of the gonads. The percentages of ovaries showing different maturation stages (immature and rudimentary stages excluded) in each season of the year were compared by a multinomial proportion analysis (Curi \& Moraes 1981). Gonadal macroscopic analysis was based on the size, form and color of the gonads, according to a previous description of JoHnson (1980) for brachyurans.

We performed a frequency distribution of the population (normality test, 5\% significance) (ZAR 1996). The organizational structure was investigated using the frequency distribution of demographic categories (juvenile males, adult males, juvenile females, adult females and ovigerous females) in 10 size classes of $4 \mathrm{~mm} \mathrm{CW}$ each. Unsexed juveniles were equally divided into male and female categories. For recruitment evaluation, the percentages of all juvenile crabs were compared using a multinomial proportion analysis among seasons (CURI \& Moraes 1981).

Only females with eggs at initial development stages were used for fecundity analysis. The egg masses were subjected to $1 \%$ sodium hypochlorite solution $(\mathrm{NaClO})$ for complete dissociation and pleopod separation. Then, each egg mass was subjected to a Motoda plankton splitter (Мотодa 1959) one to three times and counted under a stereomicroscope. The mean number of eggs was estimated and the data were visualized in a scatter plot (power function $\mathrm{y}=\mathrm{ax}^{\mathrm{b}}, \mathrm{CW}$ as the independent variable). The percentage of ovigerous females obtained in each season was compared by a multinomial proportion analysis (Curi \& Moraes 1981).

The overall sex ratio of the population, as well as the sex ratio variation according to months and size classes, was compared through Chi-square test ( $\alpha=0.05)$ (ZAR 1996).

Seasons were considered as follows: spring - October, November and December; summer - January, February and March; fall - April, May and June; and winter - July, August and September.

\section{RESULTS}

A total of 1801 crabs were captured and distributed among the following categories for population biology analysis: unsexed juveniles (41), juvenile males (331), adult males (515), juvenile females (279), adult females (453) and ovigerous females (182). The overall size-class distribution was unimodal and skewed to the right. Unsexed juveniles were present only in the first two size classes. The first adult individuals of this population were derived from from the fifth size class. Ovigerous females are present from the fifth to the ninth size class (Fig. 1).

According to the monthly distribution of individuals into size classes, juvenile crabs were present at higher proportions

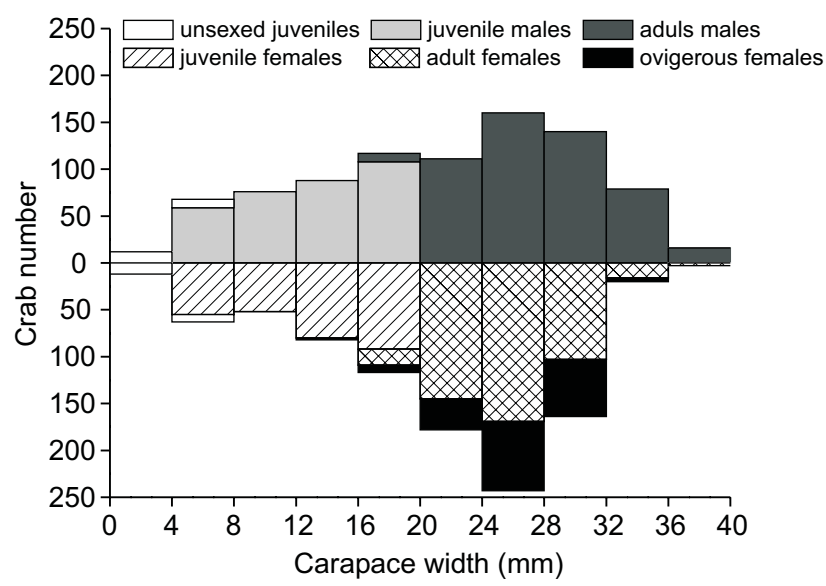

Figure 1. Size frequency distribution of $N$. granulata from mangrove of Jabaquara beach, Rio de Janeiro State, Brazil.

in April, July, August, December, February and March (Fig. 2). Recruitment occurs throughout the year, but more intensively in winter and summer months ( $p>0.05)$ (Fig. 3).

The reproductive period was considered continuous as ovigerous females were found throughout the year; however, it was more intense in the fall and winter ( $\mathrm{p}>0.05)$ (Fig. 4). Gonadal activity (over 75\%) in females was high in all four seasons of the investigated year, with no statistical differences among seasons ( $\mathrm{p}>0.05$ ) (Fig. 5).

Mean fecundity was $30028.33 \pm 10861.19$ eggs (min. 7328 and max. 53248) and the dispersion of points had its best fit represented by the equation $y=18.768 \mathrm{x}^{2.2526}\left(\mathrm{r}^{2}=0.55\right)$ (Fig. 6).

The overall sex ratio did not differ statistically (1:0.92, $\mathrm{p}$ $>0.05)$. Considering months, the proportion of males was highest in April (1:1.34), December (1:1.79) and February (1:1.48), whereas that of females was highest in May (1:0.44), June (1:0.51), July (1:0.53) and October (1:0.65, p > 0.05) (Fig. 7).

Analyzing the sex ratio according to size class, the proportion of males was higher in the third (1:1.46), ninth (1:3.95) and tenth (1:5.33) size classes, whereas females were more prevalent in the sixth and seventh classes (1:0.62 and 1:0.65, respectively, p > 0.05, Fig. 8).

\section{DISCUSSION}

A unimodal and asymmetrical frequency-distribution pattern is very common among Decapoda species from tropical regions without abrupt climatic variations, which suggests the population is in equilibrium, with continuous recruitment and a constant mortality rate (HARTNOLL \& BRYANT 1990).

Based on the frequency distribution, juveniles were scarce in the first size classes of this mangrove population. This fact was also reported by Leme (2002) for Sesarma rectum Randall, 1840 in mangroves in the north coast of the state of São Paulo. Such smaller number of individuals in the smallest size classes may be a result of sampling bias (HARTNOLL \& BRYANT 1990) or a reflec- 
unsexed juveniles $\square$ juvenile males $\square$ aduls males

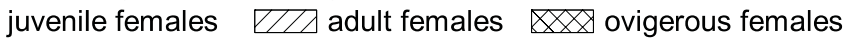
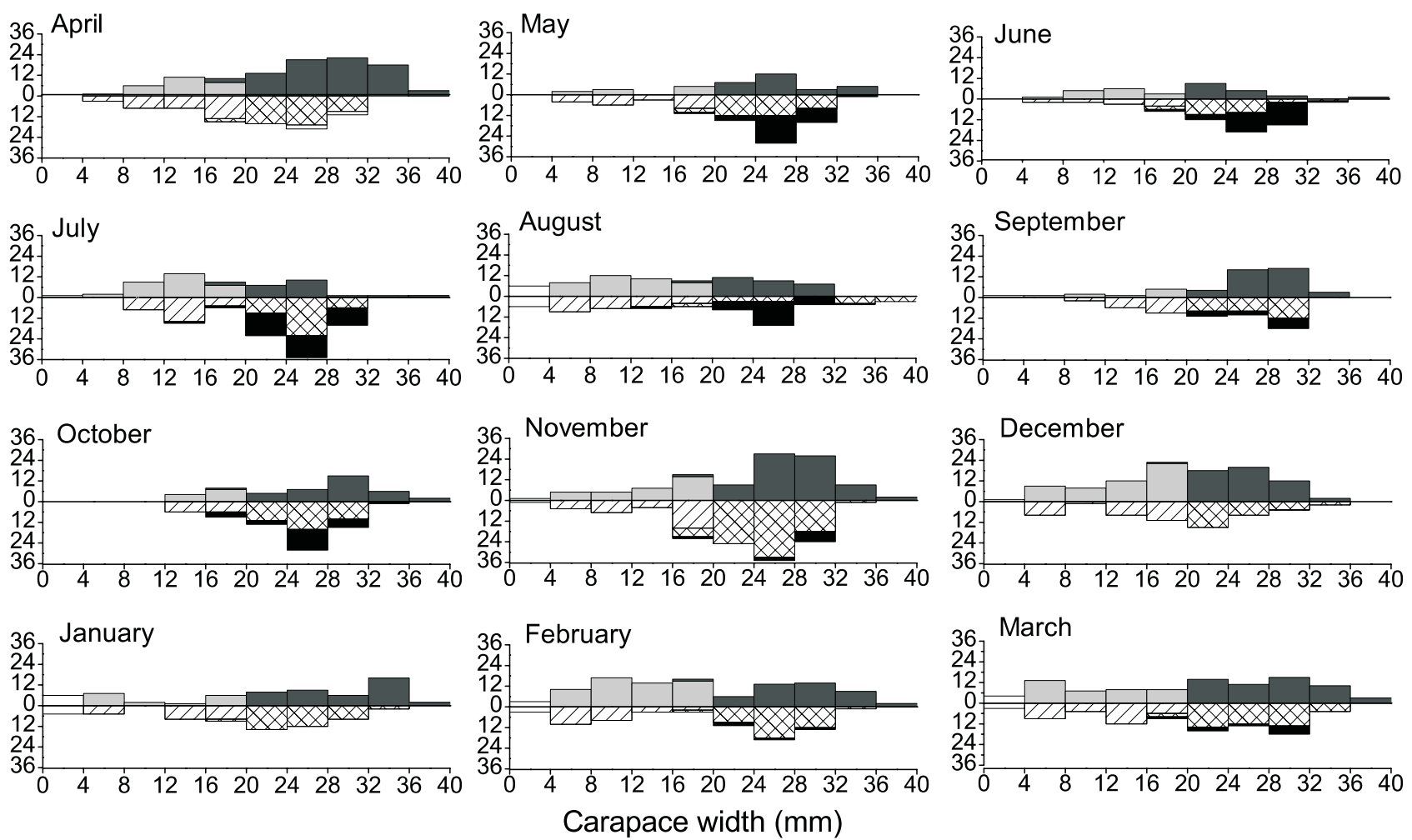

Figure 2. Size frequency distribution by months of N. granulata from a mangrove in Jabaquara beach, state of Rio de Janeiro, Brazil.
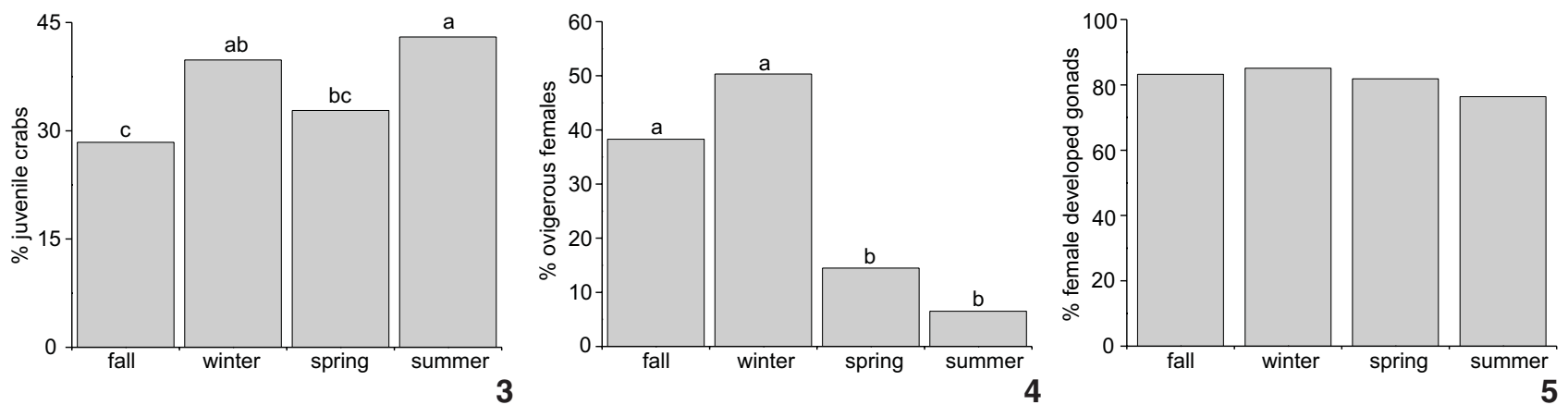

Figures 3-5. Juvenile crabs (3), ovigerous females (4) and developed female gonads percentages (5) of N. granulata from a mangrove in Jabaquara beach, state of Rio de Janeiro, Brazil. Values with at least one same letter in common did not differ statistically; $p<0.05$.

tion of the different habitat preferences by juveniles, as proposed by SPIvAK et al. (1994) for N. granulata and Cyrtograpsus angulatus Dana, 1851 from a salt marsh in Argentina. According to these authors, juvenile specimens of such species find shelter in polychaete reef formations and in a mangrove ecosystem, where the great amount of rizophores and pneumatophores may play an important role in the protection of young crabs.

Peaks of ovigerous females in continuous reproductive periods are common in brachyuran populations; however, such peaks usually coincide with months of higher environmental temperature. RufFino et al. (1994), SPIVAK et al. (1994, 1996, 2001) and Lopez-Greco \& Rodríguez (1999) have reported that $N$. granulata spawning in subtropical salt marshes occurs in almost every spring, summer and beginning of fall. SPIVAK et al. (1996) did not record ovigerous females of this species in the winter in Mar Chiquita, Argentina. 


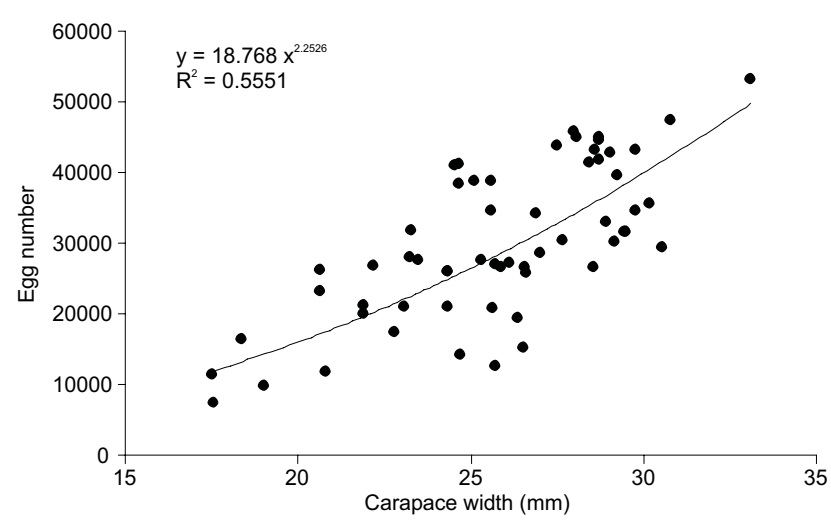

Figure 6. Fecundity of $N$. granulata from a mangrove in Jabaquara beach, Rio de Janeiro State, Brazil. (F) Egg number by ovigerous female, $(C W)$ carapace width, $\left(r^{2}\right)$ determination coefficient.

Few species are known to reproduce in cold months, like Hemigrapsus nudus (Dana, 1851), studied by KNUdSen (1964), and Ocypode quadrata (Fabricius, 1787), studied by NegreirosFransozo et al. (2002). Such pattern is also observed for $N$. granulata in the tropical mangrove population studied here.

Negreiros-Fransozo et al. (2002) evaluated some aspects of a population of $O$. quadrata from tropical beaches in north of the state of São Paulo, Brazil, and recorded a continuous reproductive period, but with greater reproductive intensity in the winter. For those authors, environmental factors such as cold ocean currents in the summer directly influence larval release. The coincidence between larval releases and planktonic peaks has also been reported by PILLAY \& NAIR (1971) for the semiterrestrial crab Uca annulipes (H. Milne Edwards, 1837) in the Indian coast. According to SASTRY (1983) and ADIYODI (1985), factors that determine the reproductive period may allow synchrony between larval release and favorable environmental conditions. Thus, although total percentages of juvenile crabs are observed throughout the year, juveniles of the first size classes recruit in the summer, which can be a result of their reproductive activity in the coldest months.

The egg number obtained in this study was higher when compared to those reported by other authors (Tab. I). Factors such as climate variations and environmental productivity (food and substrate) are the main factors influencing such differences (Seiple \& SALmon 1987, Zimmerman \& Felder 1991). These results were consistent with the general pattern for brachyurans: egg number is directly proportional to body size increase (HINEs 1982).
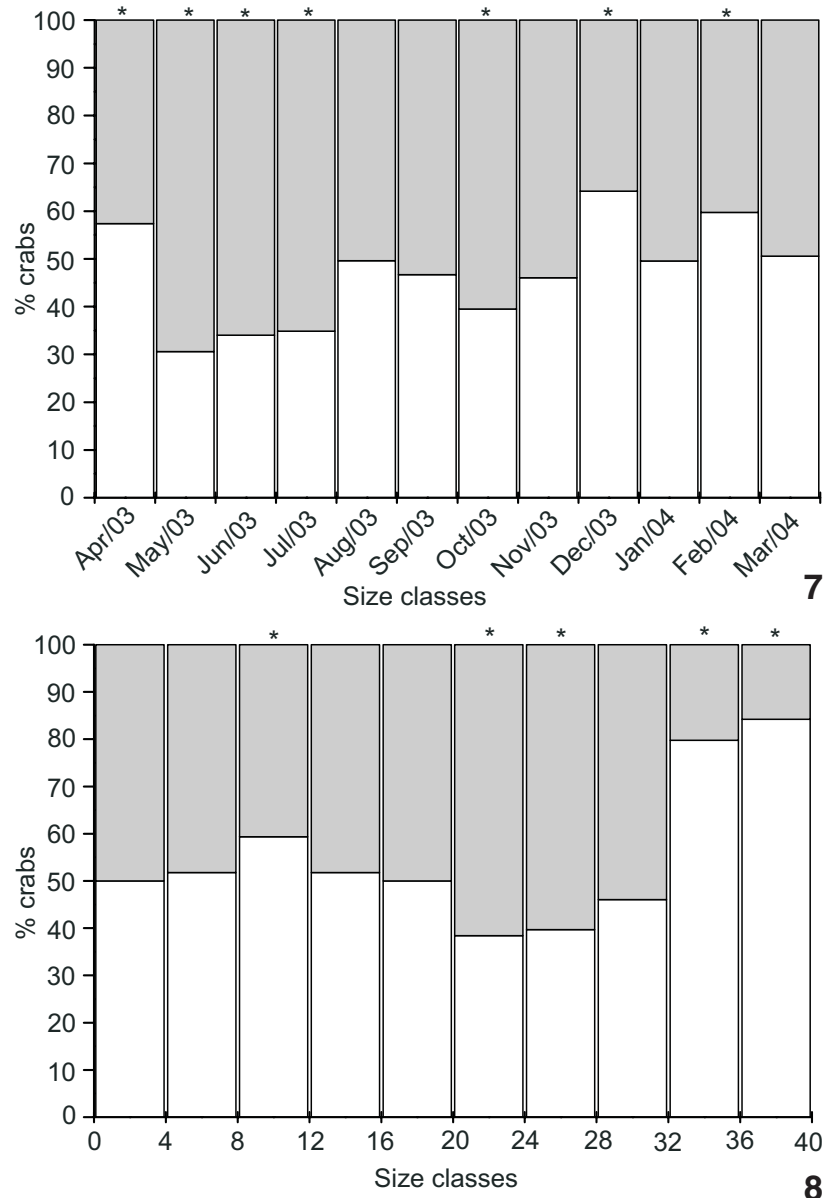

Figures 7-8. Sex ratio of $N$. granulata from a mangrove in Jabaquara beach, state of Rio de Janeiro, Brazil, by months (7) and by size classes (8) (mm CW). Bars with asterisks are statically different ( $p$ $<0.05)$. White bars = males and gray bars = females.

Luppr et al. (1997) compared the egg numbers obtained in initial and advanced stages of the embryonic development and found a considerable egg loss in the grapsoid crabs $N$. granulata and $C$. angulatus. Those authors stated that the main causes of such egg number decrease are temperature and salinity variation, pollution, parasites, egg predation, and microbial infections.

Although the percentage of ovigerous females over the year is the most common technique used to determine the reproductive period of a species (Hemni \& Kaneto 1989), the go-

Table I. Comparative fecundity of $N$. granulata in different habitats.

\begin{tabular}{lllc}
\hline \multicolumn{1}{c}{ Reference } & \multicolumn{1}{c}{ Local } & Habitat & Egg mean ( \pm SD) \\
\hline RufFINo et al. (1994) & Patos Lagoon, Rio Grande do Sul State, Brazil & Salt marsh & $19259.50 \pm 6816.30$ \\
STELLA et al. (1996) & Samborombón Bay, Argentina & Salt marsh & $27790.00 \pm 9936.00$ \\
Present work & Mangrove of Jabaquara Beach, Rio de Janeiro State, Brazil & Mangrove & $30028.33 \pm 10861.19$ \\
\hline
\end{tabular}


nadal activity frequency should also be considered. Several authors have based on female ovarian development to establish the reproductive period of crab populations (Ruffino et al. 1994, López-Greco \& Rodríguez 1999, Ituarte et al. 2004).

High percentages of females with advanced gonadal development throughout the year indicate that they have good nutrition, suggesting a highly productive environment which supplies nourishment to the crabs. The reproductive capacity of a female is related to several variables such as environmental (temperature, salinity and photoperiod) and behavioral patterns, mainly their nutritional status (WENNER et al. 1974).

The sex ratio of $N$. granulata population indicates that there is a higher proportion of male crabs in the largest size classes. This fact was also reported by Leme (2002) for S. rectum populations from the north coast of São Paulo. This differential growth between sexes can be explained by processes related to reproductive events. When females attain maturity, they grow more slowly as a result of energy allocation to egg production (WARNER 1967, CONDE \& DíAZ 1989).

This reproductive activity of females delays the somatic growth and consequently increases the number of females in some size classes, especially in reproductive size classes (DíAz \& CONDE 1989). Thus, although the overall sex ratio did not differ from that proposed by FisHer (1930), i.e. 1:1, there was a female bias in size classes with higher percentage of ovigerous specimens.

Although N. granulata has been investigated by many research groups, further comparative studies are needed to understand the variations and environmental influences concerning the latitudinal and environmental aspects of this population, as well as the reproductive biology of semiterrestrial crabs.

\section{ACKNOWLEDGEMENTS}

The authors are grateful to FAPESP (\#94/4878-8 and \#98/ 3134-6); CAPES, for the Master's fellowship to the first author; the members of Group of Studies on Crustacean Biology, Ecology and Culture (NEBECC), for the assistance; and the anonymous referees, for improving the manuscript quality. All samplings were performed according to the State and Federal laws concerning wild animals.

\section{LITERATURE CITED}

AdiYodi, R.G. 1985. Reproduction and its control, p.147-215. In: D.E. BLISS (Ed.). The biology of Crustacea, integument, pigments and hormonal processes. New York, Academic Press, 336p.

Atrill, M.J.; R.G. Hartnoll \& A.L. Rice. 1991. Aspects of the biology of the deep-sea crab Geryon trispinosus from the Porcupine Seabigth. Journal of Marine Biology of the United Kingdom 71: 311-328.

BotTo, F. \& O. IRIBARNe. 2000. Contrasting effects of two burrowing crabs (Chasmagnathus granulata and Uca uruguayensis) on sediment composition and transport in estuarine environ- ments. Estuarine Coastal and Shelf Science 51: 141-151.

Conde, J.E. \& H. Díaz. 1989. The mangrove crab Aratus pisonii in a tropical estuarine coastal lagoon. Estuarine Coastal and Shelf Science 28: 639-650.

Curi, P.R. \& R.V. MoraEs. 1981. Associação, homogeneidade e contrastes entre proporções em tabelas contendo distribuições multinomiais. Ciência e Cultura 33: 712-722.

Díaz, H. \& J.E. Conde. 1989. Populations dynamics and life history of the mangrove crab Aratus pisonii (Brachyura, Grapsidae) in a marine environment. Bulletin of Marine Science 45 (1): 148-163.

FISHER, R.A. 1930. The genetical theory of natural selection. Oxford, Oxford University Press, 219p.

González-Gurriarán, E. \& J. Freire. 1994. Sexual maturity in the velvet swimming crab Necora puber (Brachyura, Portunidae): morphometric and reproductive analyses. Journal of Marine Science 51: 133-145.

Hartnoll, R.G. \& A.D. Bryant. 1990. Size-frequency distributions in decapod Crustacea - the quick, the dead, and the cast offs. Journal of Crustacean Biology 10 (1): 14-19.

Hemni, Y. 1989. Life-history patterns in two forms of Macrophthalmus japonicus (Crustacea: Brachyura). Marine Biology 101: 53-60.

Hemni, Y. \& M. Kaneto. 1989. Reproductive ecology of three Ocypodid crabs. I. The influence of activity differences on reproductive traits. Ecological Research 4: 17-29.

Hines, A.H. 1982. Allometric constraints and variables of reproductive effort in brachyuran crabs. Marine Biology 69: 309-320.

Hutchinson, G.E. 1981. Introducción a la ecologia de poblaciones. Barcelona, Blume Editorial, 492p.

ItUARTE, R.B.; E.D. SPIVAK \& T.A. LuPPI. 2004. Female reproductive cycle of the Southwester Atlantic estuarine crab Chasmagnathus granulatus (Brachyura, Grapsoidea, Varunidae). Scientia Marina 68 (1): 127-137.

Johnson, P.J. 1980. Histology of the blue crab Callinectes sapidus: a model for the Decapoda. New York, Praeger Scientific Publishing, 440p.

Kennelly, S.J. \& D. Watkins. 1994. Fecundity and reproductive period, and their relationship to catch rates of spanner crabs, Ranina ranina of the East coast of Australia. Journal of Crustacean Biology 14 (1): 146-150.

KNUdSEn, J.W. 1964. Observations on the reproductive cycles and ecology of some common Brachyura and crablike Anomura of Puget Sound, Washington. Pacific Science 18: 3-33.

Leme, M.H.A. 2002. A comparative analysis of the population biology of the mangrove crab Aratus pisonii and Sesarma rectum (Brachyura, Grapsidae) from the North coast of São Paulo State, Brazil. Journal of Crustacean Biology 22 (3): 553-557.

López, L.S.; V.S. Stella \& E.M. Rodríguez. 1997. Size at onset of sexual maturity in Chasmagnathus granulata (Decapoda, Brachyura). Nauplius 5 (2): 65-75. 
López-Greco, L.S. \& E.M. RodríGuez. 1999. Annual reproduction and growth of adult crabs Chasmagnathus granulata (Crustacea, Brachyura, Grapsidae). Cahiers de Biologie Marine 40: 155-164.

LupPI, T.A.; C. BAS; E.D. SPIVAK \& K. Anger. 1997. Fecundity of two grapsid crab species in the Laguna Mar Chiquita, Argentina. Archives of Fisheries Marine Research 45 (2): 149 166.

LuppI, T.A.; E.D. SpIVAK; C. BAS \& K. Anger. 2004. Molt and growth of an estuarine crab, Chasmagnathus granulatus (Brachyura, Varunidae), in Mar Chiquita coastal lagoon, Argentina. Journal of Applied Ichthyology 20: 333-344.

Melo, G.A.S. 1996. Manual de identificação dos Brachyura (caranguejos e siris) do litoral brasileiro. São Paulo, Editora Plêiade, 604p.

Mотоda, S. 1959. Devices of simple plankton apparatus. Memoires of the Faculty of Fisheries Hokkaido University 7: 7394.

Negreiros-Fransozo, M.L.; A. Fransozo \& G. Bertini. 2002. Reproductive cycle and recuitment period of Ocypode quadrata (Decapoda, Ocypodidae) at a sandy beach in Southeastern Brazil. Journal of Crustacean Biology 22 (1): 157-161.

Pillay, K.K. \& N.B. NaIr. 1971. The annual reproductive cycles of Uca annulipes, Portunus pelagicus and Metapenaeus affinis (Decapoda: Crustacea) from the South-west coast of India. Marine Biology 11: 152-166.

Ruffino, M.L.; M.D. Telles \& F. D'Incao. 1994. Reproductive aspects of Chasmagnathus granulata Dana, 1851 (Decapoda, Grapsidae) in the Patos Lagoon Estuary, Brazil. Nauplius 2: 43-52.

SASTRY, A.N. 1983. Ecological aspects of reproduction, p.179270. In: F.J. Vernberg \& W.B. Vernberg (Eds). The biology of Crustacea. Environmental Adaptations. New York,
Academic Press, 383p.

Seiple, W. \& M. SALmon. 1987. Reprodutive, growth and life-history contrasts between two species of Grapsidae crabs Sesarma cinereum and Sesarma reticulatum. Marine Biology 94: 1-6.

SPIVAK, E.D.; K. Anger; T.A. Luppi; C. BAs \& D. IsmaEl. 1994. Distribution and habitat preferences of two grapsid crab species in Mar Chiquita Lagoon (Province of Buenos Aires, Argentina). Helgoländer Meeresunters 48: 59-78.

SPIVAK, E.D.; K. Anger; T.A. Luppi; C. Bas \& D. Ismael. 1996. Size structure, sex ratio, and breeding season in two intertidal grapsid crab species from Mar Chiquita lagoon, Argentina. Nerítica 10: 7-26.

SPIVAK, E.D.; T.A. LuPPI \& C. BAS. 2001. Cangrejos y camarones: las relaciones organismo-ambiente en las distintas fases del ciclo de vida, p.129-151. In: O. Iribarne (Ed.). Reserva de biósfera Mar Chiquita: características físicas, biológicas y ecológicas. Mar del Plata, Editorial Martin, 319p.

STElla, V.S.; L.S. López \& E.M. Rodríguez. 1996. Fecundity and brood biomass investment in the estuarine crab Chasmagnathus granulatus Dana, 1851 (Decapoda, Brachyura, Grapsidae). Crustaceana 69 (3): 306-312.

WARNER, G.F. 1967. The life history of the mangrove tree crab Aratus pisonii. Journal of Zoology 153: 321-335.

WENNER, A.M. 1972. Sex ratio as a function of size in marine Crustacea. American Naturalist 106: 321-350.

Wenner, A.M.; C. Fusaro \& A. OAten. 1974. Size at on set of sexual maturity and growth rate in crustacean populations. Canadian Journal of Zoology 52 (9): 1095-1106.

ZAR, J.H. 1996. Biostatistical analysis. London, Prentice-Hall, $718 \mathrm{p}$.

Zimmerman, T.L. \& D.L. Felder. 1991. Reproductive ecology of an intertidal brachyuran crab Sesarma sp. (nr. reticulatum), from the Gulf of Mexico. Biological Bulletin 181: 387-401.

Submitted: 02.V.2008; Accepted: 03.III.2009.

Editorial responsibility: Paulo Lana 